\title{
Detection of Multiple Antibodies and Risk Factor Association of Common Respiratory Viruses in the State of Punjab, India
}

\author{
P. Goswami ${ }^{1}$, H.S. Banga ${ }^{2}$, V. Mahajan ${ }^{2}$, N.D. Singh ${ }^{2}$, S. Deshmukh ${ }^{2}$ and R.S. Brar ${ }^{2}$ \\ ${ }^{1}$ Division of Veterinary Pathology, FVSc \& AH, SKUAST-K, Shuhama, Srinagar, India \\ ${ }^{2}$ Department of Veterinary Pathology, GADVASU, Ludhiana 141004, India
}

*Corresponding author

\section{A B S T R A C T}

\begin{tabular}{|c|}
\hline Keywords \\
\hline $\begin{array}{l}\text { Antibodies, } \\
\text { Bovine, BRSV, } \\
\text { IBR, PIV3, } \\
\text { Sero-prevalence } \\
\text { Punjab. }\end{array}$ \\
\hline Article Info \\
\hline $\begin{array}{l}\text { Accepted: } \\
\text { 10 February } 2017 \\
\text { Available Online: } \\
10 \text { March } 2017\end{array}$ \\
\hline
\end{tabular}

Bovine respiratory infection is considered as most important factor of economic losses in dairy herds attributed through calf mortality and reduced performances. Most of the viral etiologies in respiratory infection go unnoticed due to supervene by secondary bacterial infection. Serological presence of antibodies reflects the distribution of infectious agents in herd(s) and may be helpful for designing the prevention strategies in future. The present study encompassed to determine the antibody seroprevalences by ELISA technique to more common viral respiratory agents like Bovine Respiratory Syncytial Virus (BRSV), Parainfluenza type-3 virus (PIV3) and Infectious Bovine Rhinotracheitis (IBR) and risk factors for animal level seropositivity in dairy animals. Herd level, animal level and zone wise risk factors were analyzed. The animal level seroprevalences rates were $27.81 \%$, $47.06 \%$ and $38.50 \%$ for PIV3, BRSV and IBR, respectively. All the large to medium size herds had at least one seropositive viral infection irrespective to agents. Animals in large herd size, higher age group had highest odds of being seropositive to all viral agents. The co-infection with more than one virus is considerably common in tested animals and seropositivity for double and triple combination of the viral agents detected as 32.62 and $3.74 \%$ cases, respectively.

\section{Introduction}

Respiratory infection in bovine is most important cause of morbidity and mortality and also leads to economic losses of farmers in terms of low productivity of affected animals. The infection mostly observed in viral bacterial interaction with other stress factors plays key role in development of sub clinical to clinical disease(s). It is generally accepted that the viruses are the primary pathogen incriminating the respiratory infection and subsequently bacteria acts as the second intruder of the respiratory tract that worsen the animal condition (Valarcher and Hagglund, 2006, Solis-Calderon et al., 2007).

The most important viral pathogens include infectious bovine rhinotracheitis (IBR), bovine parainfluenza-3 (BPI-3), bovine viral diarrhea (BVD), bovine adeno virus (BAV) and bovine respiratory syncytial virus (BRSV) (Gagea et al., 2006; Fulton et al., 2009; Panciera and Confer, 2010 and Bell et al., 2014). These pathogens, along with stress and other environmental factors, have been 
shown to have a synergistic effect on each other so that the severity of the disease is worse with concurrent infections than with an individual pathogen (Brodersen and Kelling, 1998). In addition, viral pathogens have been shown to weaken the host's immune response making the host more susceptible to opportunistic pathogens (Potgieter, 1995). Viral infection can result in disease without bacterial co-infection, but the most common scenario is that viruses predispose to subsequent bacterial invasion. This is facilitated due to the viral ability to decrease the clearance system of the lung (Lopez et al., 1976; Jones, 1983 and Cusack et al., 2003). The initial viral infection is one of the most important factors in predisposing animals to secondary other viral and bacterial infections that ultimately result in BRD complex. Further factors, which predispose to disease, are the special anatomy of the bovine lung and the immune status of the host which for example might be impaired in young animals due to deficient colostral transfer (Müller, 2012). Also, environmental stressors are considered to be an important issue. One main stressor is transportation to different places e.g. auction markets (Pinchak et al., 2004; Sanderson et al., 2008). Others are weaning prior to sale, crowding and introduction of new animals into a herd. Also, poor housing conditions have an important effect on BRD (Sanderson et al., 2008; Ohlson et al., 2010 and Taylor et al., 2010). How and to what extent these factors contribute to the disease is widely debated (Taylor et al., 2010). Therefore early diagnosis and control of common viruses in the herd are keys to preventing BRD complex and the associated economic losses (USDA Part I 2002).

Amongst the viruses IBR, PIV3 and BRSV are very much common and reported worldwide. The seroprevalence of IBR has been well documented in India, however the perusal of literature showed only a solitary reports of BRSV infection from Orissa in 2002 and more recently by the author from Punjab in 2015 where as sans any seropositivity of PIV3 in bovine in India. The co-infection of presence of more than one virus is also one of the important threats to animals for being presence of multiple infections. Thus seroprevalence and detection of risk factors associated with important infection(s) are of utmost need to plan prevention or control strategies.

In the past several ancillary serological tests viz. serum neutralization test (Wellemans, 1977), ELISA (Socha and Rolla, 2013), immunofluroscence test (Potgieter and Aldridge, 1997) have been used to monitor the seroprevalence of respiratory viral infection and ELISA has been found easy and rapid with high sensitivity and specificity for detection of antibodies.

The present study was designed to elucidate the exposure of bovine to IBR, PIV3 and BRSV during 2014-2015 in Punjab encompassing the whole agroclimatic zones.

\section{Materials and Methods}

\section{Study area}

The study was focused only on Punjab state, located at $29.30^{\circ}$ north to $32.32^{\circ}$ north latitude and $73.55^{\circ}$ east to $76.50^{\circ}$ east longitude. Based on homogeneity, distribution and rainfall pattern the state is divided in to five agro climatic zones viz. Submountain undulating (Zone I), Undulating Plain (Zone II), Central Plain (Zone III), Western Plain (Zone IV) and Western zones (Zone V). The state mainly experiences tropical to subtropical climate characterized with monsoonal season and cold winter, with mean maximum temperature of $41^{\circ} \mathrm{C}$ in plain and with 2 to $5^{0} \mathrm{C}$ lower temperature at the elevated areas. The state on an average 
receives a $64.88 \mathrm{~cm}$ rainfall annually with an average humidity level ranging from $32 \%$ to $73 \%$ and the (ENVIS centre: Punjab, 2015). The total bovine population in the Punjab state has been recorded as around 76 lakh as per recent livestock record census (2012).

\section{Selection of animals}

A total of 187 bovine ( 82 cow and 105 buffalo) serum sample were collected from apparently healthy animals of 40 dairy establishment of Punjab state covering the five agroclimatic zone to determine the seroprevalence of respiratory virus viz. IBR, PIV3, BRSV. Total bovine population was 1517 of the 40 selected farms. Animals in different farms located at different agroclimatic zones were selected either by random number tables at the spot or in the laboratory using Random Animal Programme of the survey tool box software (Cameron). Both small capacity farms and intensively managed dairy herds were included in this study. Positive animals less than 150 days old were excluded from the analyses in this study to avoid interference from maternal antibodies. Sampled animals were categorized into different age groups i.e. under 1 years old, $>1$ to 4 years and above 4 years old cattle. The sampled animals were unvaccinated as no vaccination programme against these virus agents was done in the selected farms. However, animals were vaccinated against Foot and Mouth disease and Haemorrhagic septicaemia. Sampled animals were apparently healthy and did not exhibit any clinical disorder at the time of sampling. Data on potential risk factors viz. species, age of animals, zone, and herd size were recorded at each herd at the time of blood collection.

\section{Sample collection}

The experiment was carried out in accordance with the guidelines of Institutional Animal
Ethics Committee. For serum sample about $5 \mathrm{ml}$ of Blood samples from each animal were collected aseptically by jugular venipuncture method in anticoagulant free vacutainer tubes and transported on ice to laboratory. The samples were centrifuged at 1,500rpm for 10 min to obtain the serum. The sera were stored in identified vial at $-20^{\circ} \mathrm{C}$.

\section{Serological Examination}

Commercial indirect ELISA kits developed by SVANOVA Biotech, Uppsala, Sweden, and Ingezim ELISA Kit, Madrid, Spain, were used to determine the presence of antibodies to PIV3 and IBR, respectively. The sensitivity and specificity of the tests for those diseases were $99.5 \%$ and $95.4 \%$ and $97.4 \%$ and $92.4 \%$, respectively. The antibodies to BRSV were detected using a commercial available solid phase competitive enzymatic immunoassay develop by Ingezim ELISA Kit, Madrid, Spain with given sensitivity and specificity $98 \%$ and $99 \%$, respectively. The optical density (OD) was measured at $450 \mathrm{~nm}$ with a Spectrophotometer. The validity of the tests and sample OD-corrected values were calculated and interpreted as indicated in the ELISA kit. The diagnostic tests were carried out at Animal Disease Research Centre GADVASU, Punjab, India.

\section{Statistical analysis}

The results of all serum samples were used to estimate the apparent seroprevalence and true seroprevalence. The apparent seroprevalence was adjusted for specificity and sensitivity of the test to obtain true prevalence. The formulae to estimate the true prevalence (Thrusfield, 2007) was: $p=\frac{A p-\left(1-S_{p}\right)}{S_{e}-\left(1-S_{p}\right)}$ where $\mathrm{Ap}, \mathrm{Se}, \mathrm{Sp}$, and $\mathrm{p}$ are the apparent prevalence, sensitivity, specificity, and true prevalence, respectively. The confidence interval at $95 \%$ was calculated for the numbers of positive samples in the animal population used in the 
present study. Data were screened to identify explanatory variables significantly related to viral agents by using chi square test. The statistical programme SPSS package, version 16 was used to perform the statistical analysis.

\section{Results and Discussion}

A total of 187 serum sample of bovine representative of trans agroclimatic zone of Punjab were screened for the presence of PIV3, BRSV and IBR antibodies and revealed $27.81 \%, 47.06 \%$ and $38.50 \%$ respectively (Table 1).

The true animal level seroprevalence of PIV3 was estimated to be $30.36 \%$ on the basis of given sensitivity and specificity of ELISA kit as $98.5 \%$ and $95.4 \%$ respectively. The confidence level $(95 \%)$ on the apparent prevalence was calculated as $21.53-34.07 \%$. similarly for BRSV the apparent and true prevalence was calculated as $47.05 \%$ and $49.46 \%$ respectively with $95 \%$ CI ranges from 41 to $56 \%$ whereas for IBR apparent prevalence was recorded as $38.50 \%$ and true prevalence was calculated to be $34.40 \%$ with $95 \%$ CI level at 31.09 to $45.01 \%$ in the targeted bovine population.

The risk factors analysis for species wise, age factors, herd density and zone wise seroprevalence was summarized in table 2 . No differences observed in respect of presence of antibodies in cattle and buffalo for all the viral agents by chi square test $(p<0.05)$. Larger herd density $(>50$ animals in herd) and older age group ( $>4$ years) of animals were significant $>0.05$ ) on chi square analysis for the seroprevalences of all tested viral antibodies in the animals. However for the IBR seroprevalence the significant was found for age group of 1-4 years group. The seroprevalences for all viruses was observed in trans agroclimatic zones and highest seropositivity for PIV3 and IBR was observed in Zone III whereas for BRSV it was in Zone IV. The increase seroprevalence of the zone was found significant on chi square analysis.

The prevalence of multiple seropositivity for mixed infection of PIV3, BRSV and IBR was detected in the targeted farms and summarized in table 3 . It can clearly see upon investigation that $36.09 \%$ were positive for only one virus, $32.62 \%$ sera had antibodies of two different viruses. In $3.4 \%$ antibodies were simultaneously found for three different viruses. However antibodies were not detected in $26.73 \%$ of sera.

The result of the study showed most of the farm had at least one to two seropositive animals and the moderate level of individual seroprevalence of highest in case BRSV $(47.06 \%)$ followed by $\operatorname{IBR}(38.50 \%)$ and PIV3(27.81\%). It indicates that exposure to these agents was common in the region of Punjab as no clinical cases has been reported so far. Serological presence reflected natural exposure because vaccination of animals against these agents was not practiced in India. The seroprevalence of IBR was reported earlier from Punjab as well other parts of India however, increasing trends of seroprevalence was observed in recent years in the state when compared to last two years of study as evidenced as $31.20 \%$ (Mahajan et al., 2013), 36.50 (Kollanur et al., 2014). The PIV3 and BRSV was not widely reported in India earlier except few solitary reports from Orissa and sans from Punjab. Ratio of higher to low seroprevalence of these viral agents with the present study were reported globally as that reported in bovine from Iran which was $51.1 \%, 72 \%$ and $84.4 \%$ against BRSV, PIV3 and IBR respectively (Shirvani et al., 2012) and by Kojouri et al., in 2011 as 30\% for PIV3 serum antibodies. In Saudi Arabia $17.4 \%$ for IBR, $69.1 \%$ for PIV3 and $75.6 \%$ for BRSV seroprevalence was reported in 
2013 (Yousef et al., 2013). Higher seroprevalence of PIV3 and BSRV in export cattle of Australia was reported as $87 \%$ and $56 \%$ respectively, (Moore et al., 2015).

Among the 40 animal herd analyzed, larger herd size $(<50)$ showed higher seropositivity to BRSV, PIV3 and IBR. The entire herd had atleast one seropositive animal for all the viruses except five herd, where herd size/density lesser than 10 . Herd size may be considered as a potential risk factor for seropositivity of BHV-1 (chi-square $=8.22$, $\mathrm{p}=0.016$ ), BRSV (chi-square $=11.0225$, $\mathrm{p}=0.004041$ ) and PIV3 (Chi-square $=5.702, \mathrm{p}=$ $0.057)$. Thus the present study agreed with Yesilbag and Gungor (2008) who also recorded significant difference in serological prevalence of BHV-1 in large capacity farm containing >50 animals. The present result corroborate to the results of earlier studies where herd density was taken into account for potential raise for BRSV and PIV3 (SolisCalderon et al., 2007; Valarchar and Taylor 2007; Ohlson et al., 2010 and Saa et al., 2012). Management factors could also affect serological status and immunity of cattle. In the present study, animals were co-housed densely and they also shared same feeder trough and water container; resultantly the chances for ascendancy in infection may be higher in the big sized herds. The close exposure of animals to animals is expected to be greatest in larger herd might be putatively played a pivotal role in spreading of virus between animals; resultantly a higher seroprevalence of BRSV \& PIV3 in larger herd size. Further no quarantine measures are adopted by the farmer(s) for new entrants to herd whenever purchased from other region/herd, already inflicted with viral agents. The sale and purchase of animals is a regular practice in large herd farm whereas in smaller herd size most of the animals tested were native at the farm premises. The latent nature of BHV-1 in animal also re-excreted virus without apparent clinical sign thus transmits infection to other animals in a large herd.

Age is one of the important risk factor in terms of immune status of animals. In the present study, the higher seropositivity recorded for older age group of animals with advancing ages indicating an age linked seroprevalence to these viruses. Similar results were also mentioned for PIV3 virus by Figueroa-Chavez et al., (2012); Roshtkhari and Mayameel (2012) and Ezzi et al., (2013), where animals above 2 years of ages showed higher risk for seropositivity to virus. The high risk of PIV3 associated with age is due to a greater time of exposition for older animals. On the other hand, younger group of animals showed low seropositivity, this is probably because of the young age of the calves and existing maternal antibodies which may suppress the calves' own production of antibodies. This is in agreement with the conclusion of Virtala et al., (1996), wherein they reported high number of decreasing antibody titers and young pneumonic calves often fail to seroconvert to agents present in the respiratory tract because of suppressive maternal antibodies. The youngest age group ( $<1$ year old) had a significantly lower seroprevalence to BRSV than did the two older groups (>1-4 and $>4$ years old) (Chisquare test 10.66, $\mathrm{p}=0.0048$ ). Older group of animals had 4 to 6 fold higher seropositivity indicating an age associated seroprevalence to this virus. The association between higher age of animals and BRSV can be probably because the older animals are exposed for a longer time to this agent than the younger animals. Age was a significant risk factor associated with BRSV with lower prevalence in the animal $<1$ years of age in Korea (Lee et al., 2000) and 7-8 fold higher odds of seropositivity to BRSV was earlier recorded in older group of animal >4years in Mexico (Solis-Calderon et al., 2007) and in 
Iran (Shirvani et al., 2012). The present seroprevalence to BRSV increased with increasing animal age is in consonance to the findings of Luzzago et al., (2010) and Bidokhti et al., (2009). Caswell and Williams (2008) opined seroprevalence in adult animals is reported to be 40 to $95 \%$ and correlate well with disease protection. The high risk of BRSV associated with age is due to a greater time of exposition for older animals. Nevertheless BRSV re-infection can occur through life, although becoming less severe with increase in age. The capacity to produce pro-inflammatory tumor necrosis factor alpha appeared to increase with age, and may explain the age-dependent differences in respiratory syncytial virus pathogenesis (Antonis et al., 2010). Valarcher and Taylor (2007) mentioned age as important risk factors associated with BRSV.

Significantly (Chi square $=6.60, \quad p=0.037)$ higher incidence of IBR was found in cattle of age group 1-4 years as compared to other age group. These findings are in agreement with those of Aruna and Babu (1992); McDermott et al., (1997) and Mahajan et al., (2013), who reported higher seroprevalence of IBR in older animals. The increase in the prevalence of IBR with age could be due to the fact that as animals grow older, they are more likely to be exposed to the virus for prolonged duration since they are more likely to come up in to contact with other animals which have recovered from the disease but remains carriers. In this study, no seropositivity was observed in the animal's age group below 1 years of age indicating older growing age group is more susceptible to IBR infection. The immunity against BHV-1 has no direct effect on the latency state and it modulates the re-excretion of the virus (Hage et al., 1996). For the latent infections, positive serology means that the animal is a potential carrier of the virus (Bolin and Grooms, 2004) and to transmit the infection to other animals in herd.
Animals seropositivity to viral agents was calculated as per the distributions of animals in the different agroclimatic zone of the study area revealed all the zone were having seropositive animals against the primary viral agents reflecting widely distribution of these viral agents in Punjab state. However, no data is available from this region about the zonal distribution of this agent in the state. Though the prevalence amongst the zone was not found significant on chi square analysis, zone III had higher seropositive animals in respect of IBR and PIV3 whereas BRSV was observed in Zone IV followed by Zone III.

The central zone comprises of many districts and has large sized dairy farms resulting in maximum sales and purchase of animals in this zone of the state. Moreover, the stock density and mixing of the animals in closed farms allow the virus to spread (SolisCalderon et al., 2003) which might be the cause of higher prevalence of these agents in cattle in this zone. These findings were in conformity with Mahajan et al., (2013) for IBR. Significant regional differences in the frequency of BRSV have also been reported from studies in Mexico (Sarmiento-Silva et al., 2012).

However, there is no literature available about the sero-incidence of BRSV in different agroclimatic zones of Punjab. The seroprevalence of BRSV was found in transagroclimatic zones putatively due to fact that the purchase of animals from one to other region is quite prevalent in Punjab and migration of seropositive animals from one to another zone might have possibly contributed to ascendancy in seropositivity due to contagious nature of the disease. The maximum seropositivity was observed in central plain zone and western zone with nearly equal percentage and similarly to lower seropositivity in undulating plain and western plain zone. 
Table.1 Apparent and true seroprevalence of the IBR, PIV3 and BRSV in bovines of Punjab, 2015-16

\section{Total farm surveyed: 40}

Total bovine population of farm selected:1517

Animal selected for sampling: 187

\begin{tabular}{lccc}
\hline & IBR & PIV3 & BRSV \\
Animal tested positive & 72 & 52 & 82 \\
Apparent prevalence of disease (P) & $38.50 \%$ & $27.81 \%$ & $47.05 \%$ \\
True prevalence of disease & $34.40 \%$ & $30.36 \%$ & $49.46 \%$ \\
$95 \%$ confidence level & $31.09 \%$ to $45.01 \%$ & $21.53 \%$ to $34.07 \%$ & 41 to $56 \%$ \\
$(95 \% \mathrm{CI}=\mathrm{P} \pm 1.96 \times \mathrm{SE})$ & & & \\
\hline
\end{tabular}

Table.2 Risk factors analysis for species wise, age factors, herd density and zone wise serological presence of antibodies against IBR, PIV3 and BRSV in bovines of Punjab

\begin{tabular}{|c|c|c|c|c|c|}
\hline Risk factor & Categories & $\begin{array}{l}\text { Nos of } \\
\text { animals }\end{array}$ & IBR & PIV3 & BRSV \\
\hline \multirow[t]{2}{*}{ Species wise } & Cattle & 82 & $34(41.46)$ & $31(37.80)$ & $37(45.12)$ \\
\hline & Buffalo & 105 & $38(36.19)$ & $21(20.00)$ & $51(48.57)$ \\
\hline \multirow[t]{3}{*}{ Age wise abc } & $<1$ years & 9 & $0(0.00)$ & $1(11.110$ & $1(11.11)$ \\
\hline & $1-4$ years & 110 & $47(42.72)$ & $27(24.55)$ & $46(41.81)$ \\
\hline & $>4$ years & 68 & $25(36.76)$ & $24(35.30)$ & $441(60.29)$ \\
\hline \multirow[t]{3}{*}{ Herd density $^{\text {abc }}$} & $<10: 5$ herd & 13 & $1(7.690$ & $0(0.00)$ & $1(7.69)$ \\
\hline & $10-50: 24$ herd & 96 & $34(35.41)$ & $27(28.13)$ & $43(44.79)$ \\
\hline & $>50: 11$ herd & 78 & $37(47.43)$ & $25(32.05)$ & $44(56.41)$ \\
\hline \multirow[t]{5}{*}{ Zone wise } & Zone I & 33 & $10(30.30)$ & $9(27.27)$ & $9(27.27)$ \\
\hline & Zone II & 12 & $6(50.00)$ & $1(8.33)$ & $6(50.00)$ \\
\hline & Zone III & 75 & $39(52.00)$ & $25(33.33)$ & $36(48.00)$ \\
\hline & Zone IV & 21 & $2(9.52)$ & $16(76.19)$ & $5(23.80)$ \\
\hline & Zone V & 46 & 15(32.61) & $21(45.65)$ & $12(26.08)$ \\
\hline
\end{tabular}

${ }^{a} \mathrm{p}<0.05$ by chisquare test for PIV $3,{ }^{b} \mathrm{p}<0.05$ by chisquare test for BRSV, ${ }^{\mathrm{c}} \mathrm{p}<0.05$ by chisquare test for IBR

Table.3 Seropositivity distribution to one or multiple infection in bovine in Punjab

\begin{tabular}{|c|c|c|c|c|}
\hline \multirow[t]{3}{*}{ Virus } & \multicolumn{4}{|c|}{ Number of multiple infection } \\
\hline & I & & & III \\
\hline & Single & IBR & PIV3 & PIV3+IBR \\
\hline BRSV & 34 & 27 & 20 & 7 \\
\hline IBR & 24 & - & 14 & - \\
\hline PIV3 & 11 & - & - & - \\
\hline Total & $69(36.90 \%)$ & \multicolumn{2}{|c|}{$61(32.62 \%)$} & $7(3.74 \%)$ \\
\hline
\end{tabular}


The central zone and western zone comprises of many districts and has large sized dairy farms resulting in maximum sales and purchase of animals in these zones of the state. The stock density and mixing of animals in closed farms allow virus to spread (Solis-Calderon et al., 2003) which might be cause of higher prevalence of animals in central plain zone and western zone. This heterogeneity of seroprevalence may be related to regional density of dairy establishments as well as relatedness between individual herds.

The present study in table 3 displayed that the multiple infections were common amongst dairy animals of Punjab. The principal viral combinations were frequently associated with BRSV with IBR and PIV3. Mixed infection of viral components was established in most cases of bovine respiratory infections in several reports and serological studies in different parts of the world (Yavru et al., 2005; Okur-Gumusova et al., 2007; Shirvani et al., 2012; Yousef et al., 2013) and in most of the cases it was reported quadrate detection of viral antibodies to be very common which was followed by triple and double combination. The difference in multiple seropositivity in the present study, may be due to only three viral etiologies checked where in other study more than five viral etiologies were considered. The situation of mixed presence of antibodies in serum may be described by multi-agent nature of the etiology of respiratory diseases (Autio et al., 2007) or those of antibodies might be generated by individual virus infections caused in different time intervals.

\section{References}

Antonis, A.F., de Jong, M.C., van der Poel, W.H., van der Most, R.G., StockhofeZurwieden, N., Kimman, T. and Schrijver, R.S. 2010. Age-dependent differences in the pathogenesis of bovine respiratory syncytial virus infections related to the development of natural immunocompetence. J. General Virol., 91: 2497-06.

Aruna, D. and Babu, S.T. 1992. Prevalence of IBR virus antibodies in buffaloes of Andhra Pradesh. Indian J. Animal Sci., 62: 540-41.

Autio, T., Pohjanvirta, T., Holopainen, R., Rikula, U., Pentikainen, J., Huovilainen, A., Rusanen, H., Soveri, T., Sihvonen, L. and Pelkonen, S. 2007. Etiology of respiratory disease in non-vaccinated, non-medicated calves in rearing herds Vet. Microbiol., 119: 256-65.

Bidokhti, M.R.M., Traven, M., Fall, N., Emanuelson, U. and Alenius, S. 2009. Reduced likelihood of bovine corona virus and bovine respiratory syncytial virus infection on organic compared to conventional dairy farm. Vet. J., 182: 436-40.

Bell, C.J., Blackburn, P., Elliott, M., Patterson, T.I.A.P., Ellison, LahuertaMarin, S. and Ball, H.J. 2014. Investigation of polymerase chain reaction assays to improve detection of bacterial involvement in bovine respiratory disease. J. Vet. Diag. Investigation, 26: 631-34.

Bolin, S.R. and Grooms, D.L. 2004. Origination and and consequences of bovine viral diarrhea virus diversity. Vet. Clinics of North America: Food \& Animal Practice, 20: 51-68.

Brodersen, B.W. and Kelling, C.L. 1998. Effect of concurrent experimentally induced bovine respiratory syncytial virus and bovine viral diarrhea virus infection on respiratory tract and enteric diseases in calves. American J. Vet. Res., 59: 1423-30.

Caswell, J.L. and Williams, K.J. 2008. Respiratory System. In Jubb, Kennedy, and Palmer's Pathol. Domestic 
Animals. Maxie M. G (ed.) Vol 2 pp 524-617 Philadelphia, Elsevier Saunders, USA.

Cusack, P.M., McMeniman, N. and Lean, I.J. 2003. The medicine and epidemiology of bovine respiratory disease in feedlots. Australian Vet. J., 81: 480-87.

Ezzi, A., Hatami, A., Bakhshesh, M., Shoukri, M.R., Gharaghozloyan, M. 2013. Serological study of bovine herpesvirus type 1 and parainfluenza type 3 in cow farms of Qazvin province based on different ages and seasons. Arch. Razi Institute, 68: 53-57.

Figueroa-Chávez, D., Segura-Correa, J.C., García-Márquez, L.J., PescadorRubio, A., Valdivia-and Flores, A.G. 2012. Detection of antibodies and risk factors for infection with bovine respiratory syncytial virus and parainfluenza virus 3 in dual-purpose farms in Colima, Mexico. Trop. Animal Health and Production, 44: 1417-21.

Fulton, R.W., Blood, K.S., Panciera, R.J., Payton, M.E., Ridpath, J.F., Confer, A.W., Saliki, J.T., Burge, L.T., Welsh, R.D., Johnson, B.J. and Reck, A. 2009. Lung pathology and infectious agents in fatal feedlot pneumonias and relationship with mortality, disease onset, and treatments. J. Vet. Diagnosis Investigation, 21: 464-77.

Gagea, M.I., Bateman, K.G., Dreumel, T.V., McEwen, B.J., Carman, S., Archambault, M., Shanahan, R.A. and Caswell, J.L. 2006. Diseases and pathogen associated with mortality in Ontario beef feedlots. J. Vet. Diagnostic Investigations, 18: 18-28.

Hage, J.J., Schukken, Y.H., Barkema, H.W., Benedictus, G., Rijsewijk, F.A.M. and Wentink, G.H. 1996. Population dynamics of Bovine herpes virus-1 infection in a dairy herd. Vet. Microbiol., 53: 169-80.
Jones, C.D. 1983. Mucociliary clearance from the calf lung. Canadian J. Comparative Med., 47: 265-69.

Kojouri, G.A., hemmatzaleh, F. and Taghadosi, C. 2011. Serological survey of bovine parainfluenza virus type 3 in Sharhrekord district (Iran). Comparative Clin. Pathol., 20: 201-04.

Kollannur, Davis, J., Radhika, S. and Chauhan, R.S. 2014. Epidemiological Studies on Infectious Bovine Rhinotracheitis (IBR) in Different Parts of India. Int. J. Livestock Res., 4: 21-27.

Lee, Ch, Lee, K., Lee, Ch, Lee, J., Kim, S., Cho, J., Lee, C.Y., Lee, K.B., Lee, J.C., Kim, S.K. and Cho, J.J. 2000. Seroepidemiological studies on bovine respiratory syncytial virus of cattle in Chonnam province. Korean J. Vet. Clin. Med., 17: 45-51.

Lopez, A., Thomson, R.G. and Savan, M. 1976. The pulmonary clearance of Pasteurella hemolytica in calves infected with bovine parainfluenza-3 virus. Canadian J. Comparative Med., 40: 385-91.

Luzzago, C., Bronzo, V., Salvetti, S., Frigerio and Ferrari, N. 2010. Bovine respiratory syncytial virus seroprevalence and risk factors in endemic dairy cattle herds. Vet. Res. Commuication 34: 19-24

Mahajan, V., Banga, H.S., Deka, D., Filia, G. and Gupta, A. 2013. Comparison of diagnostic tests for diagnosis of infectious bovine rhinotracheitis in natural cases of bovine abortion. $J$. Comparative Pathol., 149: 391-01.

McDermott, J.J., Kadohira, M., O’Callaghan, C.J. and Shoukri, M.M. 1997. A comparsion of different models for assessing variation in seroprevalence of IBR by farm, area and district in Kenya. Preventive Vet. Med., 32: 219-34.

Moore, S.J., O’Dea, M.A., Perkins, N. and O'Hara, A.J. 2015. Estimation of nasal shedding and seroprevalence of 
organisms known to be associated with bovine respiratory disease in Australian live export cattle. J. Vet. Diagnostics Investigation, 27: 6-17.

Müller, K.E. 2012. Bedeutung von Stressoren im Komplex der Enzootischen Bronchopneumonie der Kälber und Jungrinder. Tierärztliche Umschau, 67: 55-61.

Ohlson, A., Heuer, C., Lockhart, C., Traven, M., Emanuelson, U. and Alenius, S. 2010. Risk factors for seropositivity to bovine coronavirus and bovine respiratory syncytial virus in dairy herds. Vet. Record, 167: 201-06.

Okur-Gumusova, S., Yaz, Z., Albayrak, H. and Cakiroglu, D. 2007. Seroprevalence of bovine respiratory diseases Acta Veterinaria Beograd, 57: 11-16

Panciera, R.J. and Confer, A.W. 2010. Pathogenesis and pathology of bovine pneumonia. Vet. Clin. North America: Food Animal Practice, 26: 191-24

Pinchak, E., Tolleson, D.R., McCloy M., Hunt, L.J., Gill, R.J., Ansley, R.J. and Bevers, S.J. 2004. Morbidity effects on productivity and profitability of stocker cattle grazing in the Southern Plains. $J$. Animal Sci., 82: 2773-79

Potgieter, L.N. 1995. Immunology of bovine viral diarrhea virus. Vet. Clinics for North America: Food and Animal Practice, 11: 501-20

Potgieter, L. and Aldridge, P. 1997. Use of the indirect fluroscent antibody test in the detection of bovine respiratory syncytial virus antibodies in bovine serum. American J. Vet. Res., 38: 134143.

Roshtkhari and Mayameel A. 2012. Serological evaluation of relationship between viral pathogens (BHV-1, BVDV, BRSV, PI-3V, and Adeno3) and dairy calf pneumonia by indirect ELISA. Tropical Animal Health and Production 44: 1105-10
Saa, L.R., Perea, A., Jara, D.V., Arenas, A.J., Garcia-Bocanegra, I., Borge, C. and Carbonero, A. 2012. Prevalence and risk factors for bovine respiratory syncytial virus (BRSV) infection in non-vaccinated dairy and dual-purpose cattle herds in Eucador. Trop. Animal Health and Production, 44: 1423-27

Sanderson, M.W., Dargatz, D.A. and Wagner, B.A. 2008. Risk factors for initial respiratory disease in United States' feedlots based on producer-collected daily morbidity counts. Canadian Vet. J., 49: 373-78

Sarmiento-Silva, R.E., Nakamura-Lopez, Y. and Vaughan, G. 2012. Epidemiology, molecular epidemiolofy and evolution of bovine respiratory syncytial virus. Viruses, 4: 3452-67

Shirvani, E., Lotfi, M., Kamalzadeh, M., Noaman, V., Bahriari, M., Morovati, H. and Hatami, A. 2012. Seroepidemiological study of bovine respiratory viruses in dairy cattle in central region of Iran (Esfahan Province). Tropical Animal Health and Production 44: 191-95

Socha, W. and Rolla, J. 2013. Prevalence of bovine respiratory syncytial virus (BRSV) infections in cattle population in Poland. Medycyna Weterynaryina 69: 288-90

Solis-Calderon, J.J., Correa, J.C., Aguilar Romero, F. and Segura Correa, V. M. 2007. Detection of antibodies and risk factors for infection with bovine respiratory syncytial virus and parainfluenza virus-3 in beef cattle of Yucatan, Mexico. Preventive Vet. Med., 82: 102-10

Solis-Calderon, S.J., Correa, V.M., Correa, J.C. and Islas, A.A. 2003. Seroprevalence and risk factors for IBR in beef cattle herds of Yctan Mexico. Preventive Vet. Med., 57: 199-08

Taylor, J.D., Fulton, R.W., Lehenbauer, T.W., 
Step, D.L. and Confer, A.W. 2010. The epidemiology of bovine respiratory disease: What is the evidence for predisposing factors? Canadian Vet. J., 51: 1095-02

USDA. Part I. 2002. Reference of dairy health and management in the United States. Fort Collins (CO): USDA: APHIS: VS, CEAH. National Animal Health Monitoring System, N377.1202

Valarcher, J.F. and Hagglund, S. 2006. Viral respiratory infections in cattle. In: Proceedings of the $24^{\text {th }}$ World Buiatrics Congress May 22-25. Nice, France.

Valarcher, J.F. and Taylor, G. 2007. Bovine respiratory syncytial virus infection, Review article, Vet. Res., 38: 153-80

Virtala, A.M.K., Mechor, G.D., Grohn, Y., Erb, H.N. and Dubovi, E. 1996. Epidemologic and pathologic characteristic of respiratory tract disease in dairy heifer during the first three month of life. J. American Vet. Med. Association, 208: 2035-42

Wellemans, G. 1977. Laboratory diagnosis methods for bovine respiratory syncytial virus. Vet. Sci. Communication 1: 17989.

Yavru, S., Simsek, A., Yapkico, O. and Kale, M. 2005. Serological evaluation of viral infection in bovine respiratory tract. Acta Vet., 2: 219-26.

Yesilbag, K. and Gungor, B. 2008. Seroprevalence of bovine respiratory viruses in North-Western Turkey. Trop. Animal Health Production, 40: 55-60.

Yousef, M.R., Mahmoud, M.A.F., Ali, S.M. and Blowi, M.H. 2013. Seroprevalence of some bovine respiratory diseases among non vaccinated cattle in Saudi Arabia. Vet. World, 6: 1-4.

\section{How to cite this article:}

Goswami, P., H.S. Banga, V. Mahajan, N.D. Singh, S. Deshmukh and Brar, R.S. 2017. Detection of Multiple Antibodies and Risk Factor Association of Common Respiratory Viruses in the State of Punjab, India. Int.J.Curr.Microbiol.App.Sci. 6(3): 567-577.

doi: https://doi.org/10.20546/ijcmas.2017.603.066 